\title{
RANCANG BANGUN PROTOTYPE SISTEM PENDETEKSI PELANGGARAN PADA ZEBRA CROSS DI LAMPU LALU LINTAS BERBASIS ARDUINO
}

\author{
Uswatun Hasanah $^{1)}$, Mery Subito ${ }^{2)}$, Muh Aristo Indrajaya ${ }^{3)}$ \\ ${ }^{1)}$ Mahasiswa Teknik Elektro Universitas Tadulako ${ }^{2}$ Dosen Teknik Elektro Universitas Tadulako \\ Program Studi S1 Teknik Elektro, Fakultas Teknik, Universitas Tadulako \\ E-mail : Ucchaaa27@gmail.com
}

\begin{abstract}
Current road users cannot be separated from the number of violators, therefore traffic lights are made to regulate traffic on the road. At traffic lights, there is also a zebra crossing which serves as a means of crossing the road for pedestrians. To minimize violations at road intersections, researchers designed a tool to detect traffic violations.

Traffic violation detection tool is made in prototype form using a control system with Arduino nano and software. This traffic light system uses LDR and laser sensors to detect these violations by cutting the laser which sends light to the LDR. This tool is also equipped with a webcam camera that functions to photograph violations that occur and a buzzer that functions as a warning to officers and riders in the event of a violation with an average response speed of the webcam of 2.37 seconds and the average response speed of the buzzer is 0.4 seconds. . The snapshot from the webcam is saved automatically on your PC / Laptop.
\end{abstract}

Keyword : detection system, sensor, automatic, webcam, crime.

\section{PENDAHULUAN}

Pada zaman sekarang kendaraan merupakan alat transportasi yang paling penting untuk mempermudah pekerjaan masyarakat. Indonesia adalah salah satu negara yang hampir setiap penduduknya merupakan pengguna kendaran, baik itu kendaraan roda dua maupun roda empat.

Pengguna jalan saat ini juga tidak lepas dari banyaknya pelanggar, maka lampu lalu lintas dibuat untuk mengatur lalu lintas pada jalan. Pada lampu lalu lintas juga terdapat zebra cross sebagai sarana tempat untuk menyebrang jalan. Zebra cross berfungsi memberikan prioritas bagi pejalan kaki untuk menyebrang jalan. Namun pada saat ini masih banyak pengendara yang melanggar dengan melewati maupun berhenti tepat pada zebra cross. Sehingga sarana untuk para pejalan kaki untuk menyebrang diambil oleh para pengguna kendaraan. Peraturan hukum mengenai zebra cross telah dijelaskan pada Undangundang nomor 22 Tahun 2009 tentang Lalu Lintas dan Angkutan Jalan (LLAJ), pasal 131 Ayat (2), disebutkan bahwa "Pejalan kaki berhak mendapatkan prioritas pada saat menyebrang jalan di tempat penyebrangan". Dan Pasal 106 Ayat (2), disebutkan bahwa "Setiap orang yang akan mengemudikan kendaraan bermotor di jalan wajib mengutamakan keselamatan pejalan kaki dan pesepeda".

Salah satu solusi yang bisa digunakan untuk meminimalisir pelanggaran pada zebra cross dan untuk kenyamanan pengguna zebra cross adalah dengan menerapkan pendeteksi pelanggaran secara visual yang diintegrasikan dengan pola pengatur lampu lalu lintas. Maka dari itu penulis mengangkat judul tugas akhir "Rancang Bangun Prototype Sistem Pendeteksi Pelanggaran Pada Zebra Cross Di Lampu Lalu Lintas Berbasis Arduino" 


\section{METODE PENELITIAN}

\subsection{Alat dan Bahan}

Adapun alat dan bahan yang diperlukan dalam penelitian ini adalah sebagai berikut :

Tabel 1. Daftar Alat dan Bahan

\begin{tabular}{|c|c|c|c|}
\hline NO & $\begin{array}{c}\text { Nama } \\
\text { Komponen }\end{array}$ & Tipe & Jumlah \\
\hline 1 & $\begin{array}{c}\text { Mikrokontr } \\
\text { oler }\end{array}$ & $\begin{array}{c}\text { Arduino } \\
\text { Nano }\end{array}$ & 2 buah \\
\hline 2 & Sensor & LDR & 1 buah \\
\hline 3 & $\begin{array}{c}\text { Modul } \\
\text { Traffic } \\
\text { Light }\end{array}$ & - & 4 buah \\
\hline 4 & Webcam & X85 & 1 buah \\
\hline 5 & Buzzer & - & 1 buah \\
\hline 6 & Papan PCB & - & 1 buah \\
\hline 7 & $\begin{array}{c}\text { Kabel } \\
\text { Jumper }\end{array}$ & - & 1 set \\
\hline 8 & Laser & - & 1 buah \\
\hline
\end{tabular}

\subsection{LDR (Light Dependent Resistor)}

LDR atau Light Dependent Resistor adalah salah satu jenis resistor yang nilai hambatannya dipengaruhi oleh cahaya yang diterima olehnya. Besarnya nilai hambatan pada LDR tergantung pada besar kecilnya cahaya yang diterima oleh LDR itu sendiri.

LDR adalah suatu bentuk komponen yang mempunyai perubahan resistansi yang besarrnya tergantung pada cahaya. Karakteristik LDR terdiri dari dua macam yaitu Laju Recovery dan Respon Spektral :

\section{Laju Recovery}

Bila sebuah LDR dibawa dari suatu ruangan dengan level kekuatan cahaya tertentu kedalam suatu ruangan yang gelap, maka bisa kita amati bahwa nilai resistansi dari LDR tidak akan segera berubah resistansinya pada keadaan ruangan gelap tersebut. Namun LDR tersebut hanya akan bisa mencapai harga kegelapan setelah mengalami selang waktu tertentu. Laju recovery merupakan suatu ukuran praktis dan suatu kenaikan nilai resistansi dalam waktu tertentu. Harga ini ditulis dalam K/detik, untuk LDR tipe arus harganya lebih besar dari 200K/detik(selama 20 menit pertama mulai dari level cahaya 100 lux), kecepatan tersebut akan lebih tinggi pada arah sebaliknya, yaitu pindah dari tempat gelap ke tempat terang yang memerlukan waktu kurang dari $10 \mathrm{~ms}$ untuk mencapai resistansi yang sesuai dengan level cahay 400 lux.

2. Respon Spektral

LDR tidak mempunyai sensitivitas yang sama untuk setiap gelombang cahaya yang jatuh padanya (yaitu warna). Bahan yang biasa digunakan sebagai penghantar arus listrik yaitu tembaga, aluminium, baja, emas dan perak. Dari kelima bahan tersebut tembaga merupakan penghantar yang paling banyak, digunakan karena mempunyai daya hantar yang baik[11].

Resistansi LDR akan berubah seiring dengan perubahan intensitas cahaya yang mengenainya atau yang ada disekitarnya. Dalam keadaan gelap resistansi LDR sekitar $10 \mathrm{M} \Omega$ dan dalam keadaan terang sebesar $1 \mathrm{~K} \Omega$ atau kurang. LDR terbuat dari bahan semikonduktor seperti cadmium sulfide. Dengan bahan ini energy dari cahaya yang jatuh menyebabkan lebih banyak muatan yang dilepas atau arus listrik meningkat. Artinya resistansi bahan telah mengalami penurunan. [12]

\subsection{Mikrokontroler Arduino Nano}

Dalam tulisan [2] menjelaskan tentang Arduino Nano adalah sebuah board yang mempunyai ukuran kecil yang rancang 
berdasarkan Atmega 328 atau Atmega168. Dengan ukuran yang kecil board ini sangat praktis digunakan sehingga membuatnya menjadi mikrokontroler paling popular. Board ini memiliki kekurangan yaitu tidak memiliki port untuk DC power. Dan bekerja hanya dengan kabel Mini-B USB. Board arduino nano didesain dan diproduksi oleh Gravitech (Arduino, 2016). Berikut gambar 1 yang menunjukan bentuk fisik Arduino Nano.

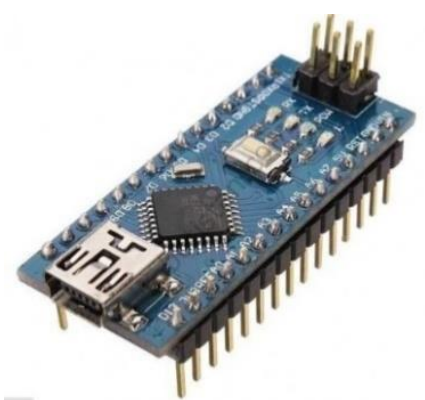

Gambar 1. Arduino Nano

\subsection{Webcam}

Webcam merupakan gabungan dari kata web dan camera. Webcam sendiri sebutan bagi kamera real-time (bermakna keadaan pada saat ini juga) yang gambarnya bisa di akses atau dilihat melalui internet, program instant messaging seperti Yahoo Messenger, AOL Instant Messenger (AIM), Windows Live Messenger, dan Skype, dan lainnya. Istilah "webcam" sendiri mengarah pada jenis kamera yang digunakan untuk kebutuhan layanan berbasis web. Webcam biasanya digunakan untuk keperluan konferensi jarak jauh atau juga sebagai kamera pemantau. Pada gambar 2 menunjukan bentuk dari webcam.

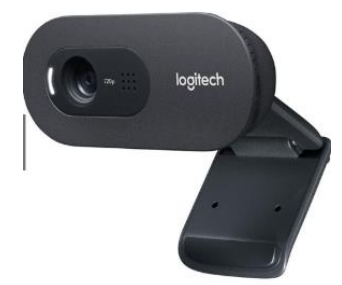

Gambar 2. Webcam

\subsection{Buzzer}

Buzzer adalah sebuah komponen elektronika yang berfungsi untuk mengubah getaran listrik menjadi getaran suara. Pada dasaranya prinsip kerja buzzer hampir sama dengan loud speaker, jadi buzzer juga terdiri dari kumparan yang terpasang pada diafragma dan kemudian kumparan tersebut dialiri arus sehingga menjadi electromagnet.

Kumparan tadi akan tertarik kedalam atau keluar, tergantung dari arah arus dan polaritas magnetnya, karena kumparan dipasang pada diafragma maka setiap gerakan kumparan akan menggerakan diafragma secara bolak-balik sehingga membuat udara bergetar yang akan menghasilkan suara. Buzzer biasa digunakan sebagai indikator bahwa proses telah selesai atau terjadi suatu kesalahan pada sebuah alat (alarm). Berikut gambar 3 menunjukan bentuk fisik buzzer yang digunkan.

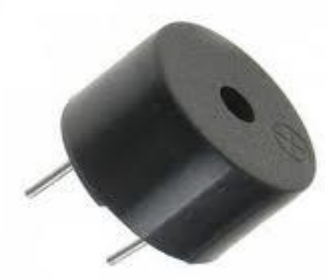

Gambar 3. Buzzer

\subsection{Laser}

Dioda laser atau dalam bahas Inggris disebut dengan Laser Diode adalah komponen semikonduktor yang dapat menghasilkan radiasi koheren yang dapat dilihat oleh mata ataupun dalam bentuk spectrum inframerah (Infrared/IR) ketika dialiri arus listrik. Yang dimaksud dengan radiasi koheren adalah radiasi dimana semua gelombang berasal dari satu sumber yang sama dan berada pada frekuensi dan fasa yang sama juga. Kata "laser" merupakan singkatan dari (Light Amplification by 
Stimulated Emission of Radiation) yang artinya adalah mekanisme dari suatu alat yang memancarkan radiasi elektromaknetik melalui proses pancaran terstimulasi. Radiasi elektromaknetik tersebut ada yang dapat dilihat oleh mata normal, ada juga yang tidak dapat dilihat. Panjang gelombang (Wavelength) terlihat yang terbuat dari gas dioda laser pertama kali diperkenalkan oleh Nick Holonyok Jr yaitu seorang Ilmuwan yang bekerja di general electric pada tahun 1962. Pada dasarnya, dioda laser hanyalah salah satu jenis perangkat ataupun teknologi yang dapat menghasilkan sinar laser. Jenisjenis perangkat ataupun teknologi lainnya yang dapat menghasilkan sinar laser diantaranya adalah Solid-state Laser, Laser Gas, Laser Excimer dan Dye Laser.

Pada dasarnya, diode laser hampir sama dengan Lampu LED yaitu dapat mengkonversi energy listrik menjadi energi cahaya, namun diode laser dapat menghasilkan sinar/cahaya atau beam dengan intensitas yang lebih tinggi.

Berdasarkan cara kerjanya, Dioda Laser dapat dibedakan menjadi 2 jenis yaitu Injection Laser Diode (ILD) dan Optically Pumped Semiconductor Laser.

1. Injection Laser Diode (ILD)

Cara kerja Injection Laser Diode memiliki berbagai kemiripan dengan LED (Light Emitting Diode). Kedua-duanya dibuat berdasarkan proses dan teknologi yang hampir sama. Perbedaan utama pada Dioda Laser adalah adanya sebuah saluran atau kanal panjang yang sempit dengan ujung yang reflektif. Kanal tersebut berfungsi sebagai penuntun gelombang pada cahaya. Kanal tersebut biasanya disebut dengan Waveguide.

Pada pengoperasiannya, arus mengalir melalui persimpangan $\mathrm{PN}(P N$ Junction) dan menghasilkan cahaya seperti pada LED (Light Emitting Diode). Pancaran fotonnya (Photon) disebabkan oleh bergabungnya kembali Elektron dan Lubang
(Holes) di daerah persimpangan PN. Namun cahaya tersebut hanya dibatasi didalam waveguide (penuntun cahaya) pada dioda laser sendiri. Di waveguide ini cahaya laser direfleksikan dan kemudian diperkuat sehingga menghasilkan emisi terstimulasi sebelum dipancar keluar.

2. Optically Pumped Semiconductor Laser

Optically Pumped Semiconductor Laser atau disingkat dengan OPSL ini menggunakan chip semikonduktor III-V sebagai dasarnya, Chip semikonduktor ini bekerja sebagai media penguat optik. Dioda laser yang terdapat didalamnya berfungsi sebagai sumber pompa. Terdapat beberapa keuntungan dari dioda laser jenis Optically Pumped Semiconductor Laser ini, terutama dalam pemilihan panjang gelombang (wavelenght) dan mengurangi gangguan dari struktur elektroda internal.
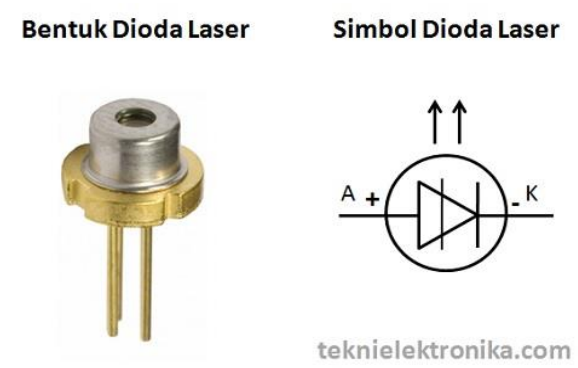

Gambar 4. Bentuk Dioda Laser dan Simbol Dioda Laser 


\section{HASIL DAN PEMBAHASAN}

\subsection{Hasil Penelitian}

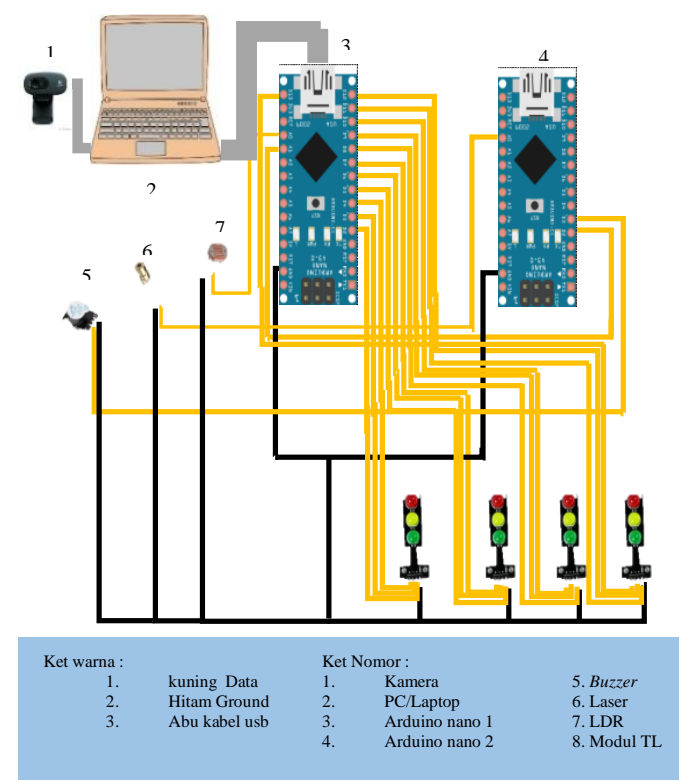

Gambar 5. Skematik rangkaian alat

Dari hasil perancangan dan penelitian ini dilakukan pengujian alat yang dilakukan beberapa kali untuk melihat tingkat keberhasilan sensor pada saat mendeteksi maupun tingkat keberhasilan sistem secara keseluruhan

Dalam penelitian ini menggunakan Arduino Nano yang berfungsi sebagai pengolah data masuk (input) dan data keluar (output), penggunaan input pada Arduino nano tersebut antara lain sensor LDR melalui pengiriman data yang masuk melalui pin analog input. Sedangkan penggunaan output dari Arduino nano, yaitu untuk laser, modul traffic light dan buzzer yang masuk melalui pin digital output.

Pada penelitian ini sendiri peneliti menggunakan dua Arduino nano, Arduino yang pertama digunakan untuk mengontrol lampu lalu lintas dan laser. Arduino yang kedua digunakan untuk mengontrol sensor LDR, buzzer dan pengiriman data ke PC/laptop. Untuk perangkat output yaitu lampu lalu lintas diinputkan dari pin 2 sampai 13, laser diinputkan ke pin A0, dan untuk pin A1 digunakan sebagai inputan mengirim data ke Arduino yang kedua melalui pin D2. Pada Arduino yang kedua perangkat inputannya yaitu sensor LDR diinputkan ke pin A0, sedangkan outputnya yaitu buzzer di pin 3, dan komunikasi Arduino nano dengan laptop melalui komunikasi serial.

Pengujian dilakukan dengan memotong cahaya laser ke sensor LDR dan kemudian sensor mendeteksi terjadinya pelanggaran, webcam mengambil gambar selama pelanggaran tersebut terjadi lalu dilihat lama selang waktu respon LDR mendeteksi pelanggaran dan webcam mengambil gambar pada saat terjadi pelanggaran

Begitu juga dengan pengujian buzzer ketika sensor LDR mendeteksi terjadinya pelanggaran maka buzzer akan berbunyi atau aktif.

Adapun tampilan grafik respon alat aalah sebagai berikut :

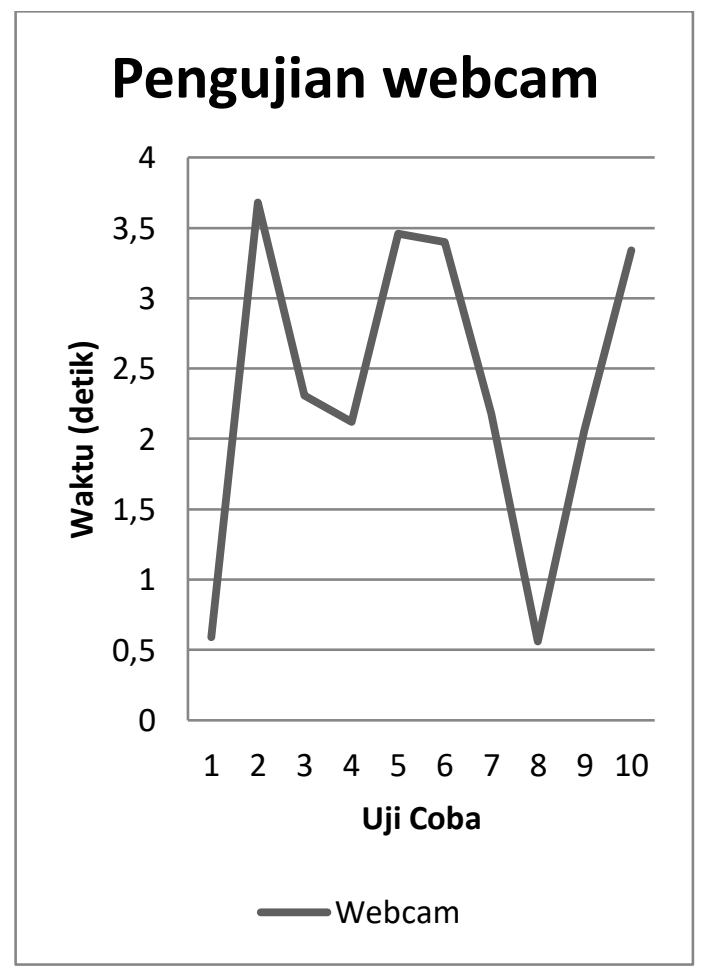

Gambar 6. Grafik respon webcam 
Di lihat dari gambar 6 rata-rata waktu yang digunakan untuk webcam merespon adalah 2.37 detik, waktu respon webcam paling cepat 0.56 detik dan waktu respon webcam paling lama yaitu 3.68 detik. Percobaan ini dilakukan sebanyak 10 kali percobaan pelanggaran.

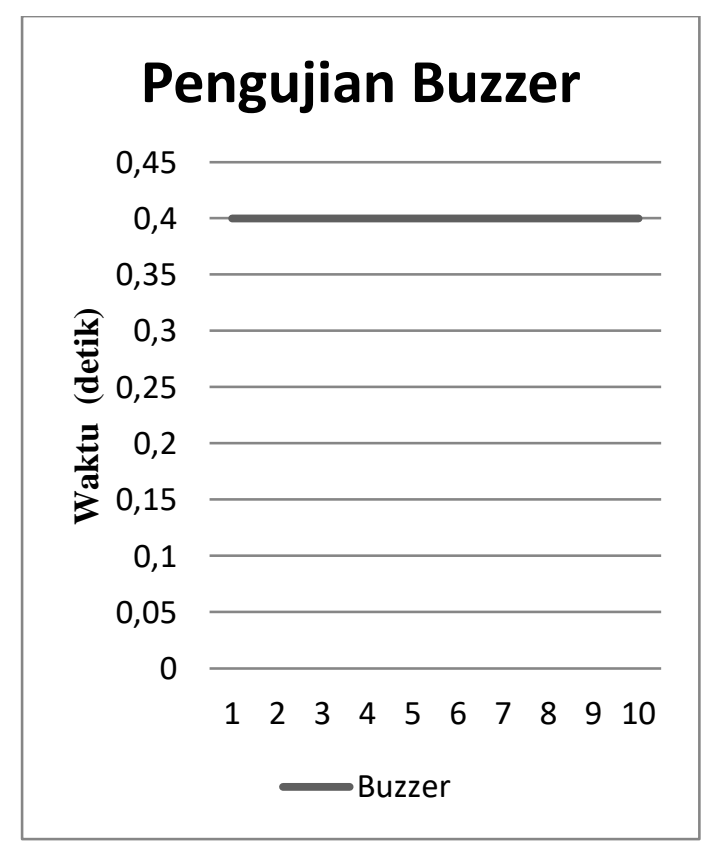

Gambar 7. Grafik respon Buzzer

Pada gambar yaitu hasil pengujian waktu buzzer aktif didapatkan hasil dari waktu respon buzzer rata-rata 0.4 detik atau konstan, ini menunjukan bahwa kinerja dari buzzer sangat baik. Percobaan ini dilakukan sebanyak 10 kali percobaan pelanggaran.

\section{KESIMPULAN}

Dari hasil pengujian alat dan pengambilan data yang telah dilakukan pada penelitian dengan judul Rancang Bangun Prototype Sistem Pendeteksi Pelanggaran pada Zebra Cross di Lampu Lalu Lintas Berbasis Arduino, maka dapat diperoleh kesempulan sebagai berikut :

1. Rancang bangun pendeteksian pelanggaran pada lampu lalu lintas dibuat dengan menggunakan sensor
LDR sebagai penerima data dan Laser sebagai pengirim data, apabila laser terpotong oleh kendaraan yang berhenti di zebra cross maka LDR tidak menerima data dan pelanggaran terdeteksi selanjutnya buzzer akan aktif dan webcam akan memotret pelanggaran yang terjadi, hasil dari potret webcam akan tersimpan otomatis di PC/Laptop.

2. Keseluruhan kinerja sistem alat pendeteksi pelanggaran pada lampu lalu lintas di zebra cross berjalan dengan sangat baik. Berdasarkan hasil pengujian, setiap pelanggaran lalu lintas yang terjadi dapat dideteksi oleh sensor dan capture oleh webcam. Webcam juga dapat mengcapture pelanggaran yang terjadi secara beruntun.

3. Dari hasil penelitian terdapat beberapa pengujian yang dilakukan yaitu yang pertama pengujian kalibrasi sensor LDR nilai tertinggi apabila tidak ada cahaya yaitu 252 dan terendah 226, rata-ratanya 241.8 sedangkan jika tidak ada cahaya nilai dari sensor LDR yaitu 0 . Yeng kedua pengujian waktu respon webcam rata-rata waktu respon dari webcam yaitu 2.37 detik, waktu respon webcam paling cepat yaitu 0.56 detik dan paling lama yaitu 3.68 detik. Dan yang terakhir pengujian waktu respon buzzer didapatkan rata-rata waktunya yaitu 0.4 detik dan konstan. Dari setiap pengujian dilakukan percobaan sebanyak 10 kali percobaan pelanggaran.

\section{DAFTAR PUSTAKA}

[1] Aji Brahma Nugroho. 2019. Sistem Pemantau Pelanggaran Lalu Lintas Pada Lampu lalu lintas Menggunakan Sensor SRF04 Dan Kamera Berbasis Mikrontroler AtMega8535. Jurusan Teknik Elektro, Universitas 
Muhammadiyah Jember, Indonesia. Vol. 1 No. 1, Agustus 2019.

[2] Angger Dimas Bayu Sadewo dkk, Perancangan Pengendali Rumah menggunakan Smartphone Android dengan Konektivitas Bluetooth ,Jurnal Pengembangan Teknologi Informasi dan Ilmu Komputer e-ISSN: 2548964X Vol. 1, No. 5, Mei 2017.

[3] Budiharto, Widodo. 2011. Aneka Proyek Mikrokontroler Panduan Utama Untuk Riset/Tugas Akhir. Jakarta : Graha Ilmu.

[4] Fendi Pradana, 2020. Rancang Bangun Sistem Pengamanan Gedung yang Dikontrol Melalui Aplikasi Android Berbasis IoT. Program Studi S1 Teknik Elektro, Fakultas Teknik, Universitas Tadulako.

[5] Muchamad Affan, 2016. Rancang Bangun Pendeteksi Pelanggaran Pada Lampu lalu lintas Berbasis Mikrokontroler. Program Studi D3 Otomasi Sistem Instrumentasi, Departemen Teknik, Universitas Air Langga .

[6] Rachmat Hidayat S, Abdur Rabi', dan Elta Sonalitha, 2020. System Pendeteksi Pelanggar Lampu lalu lintas pada Zebra Cross Menggunakan Raspberry $\mathrm{Pi}$ Berbasis Pengolahan Citra Digital. Program Studi Teknik Elktro, Universitas Merdeka Malang.

[7] Rudi Kurniawan, Veronica Ernita kristianti, Alona Situmeang. 2019. Alat Pendeteksi Pelanggaran Pada Persimpangan Lalu Lintas Satu Arah Menggunakan Sensor Laser Berbasis Arduino Mega 2560. Fakultas Teknologi Industri, Universitas Gunadarma.

[8] Suman, Singha dan Debasis Maji., 2016. Laser Security System. International Journal of Scientific \& Engineering Research.

[9] Undang - Undang No.22 Tahun 2009 Tentang Lalu Lintas Dan Angkutan Jalan (LLAJ) Pasal 131 Ayat 2.

[10] Wongsokuncoro, et al, 2016. Rancang Bangun Pendeteksian Pelanggaran pada Lampu lalu lintas Berbasis Mikrokontroler. Surabaya, Perpustakaan Universitas Airlangga.
[11] Christian Memesah, Pengunaan Motor dan Sistem Kontrol, TEDC,1998.

[12] Sri Supatmi, 2011. Pengaruh Sensor LDR Terhadap Pengontrolan Lampu Jurusan Teknik Komputer Universitas Indonesia 